A N N A L E S

UNIVER S T ATIS M A R A E C URIE-SKŁODOW K A

LUBLIN - POLONIA

VOL. XXXI, 3

SECTIO J

2018

Uniwersytet Marii Curie-Skłodowskiej w Lublinie. Wydział Pedagogiki i Psychologii

\title{
DANUTA WOSIK-KAWALA
}

ORCID: 0000-0003-2846-7203

danuta.wosik-kawala@poczta.umcs.lublin.pl

\section{Uwarunkowania skuteczności procesu wychowania w środowisku szkolnym}

Determinants of the Effectiveness of the Education Process in the School Environment

\section{STRESZCZENIE}

Współcześnie od szkoły oczekuje się, aby była instytucją wychowującą, chroniącą indywidualność jednostki, pomagającą jej w kierowaniu własnym rozwojem i w dążeniu do samorealizacji, przygotowującą do wartościowego uczestnictwa w życiu społecznym. Mimo że wychowanie w szkole dokonuje się każdego dnia przez interakcje z wszystkimi nauczycielami i rówieśnikami, to za efekty procesu wychowawczego odpowiedzialny jest głównie nauczyciel, zwłaszcza wychowawca klasy. Artykuł ma charakter analityczno-przeglądowy. Ukazano teoretyczny kontekst dotyczący podstawowych czynników wpływających na skuteczność procesu wychowania realizowanego w środowisku szkolnym. Wychowanie rozumiane jest tutaj jako proces kształtowania młodego człowieka. Zostało ono określone za pomocą pięciu głównych cech. Autorka zwraca uwagę, iż osoby zajmujące się wychowaniem z racji pełnionej roli zawodowej powinny opierać się na jasno określonych wytycznych, sformułowanych w sposób przejrzysty i czytelny, uwzględniających podstawowe zasady współżycia międzyludzkiego, a nie jedynie na intuicji i własnym doświadczeniu.

Słowa kluczowe: szkoła; wychowanie; nauczyciel; uczeń

\section{WPROWADZENIE}

Wychowanie i problemy z nim związane są tematem rozmów, a nawet burzliwych dyskusji, podejmowanych zarówno przez osoby zawodowo zajmujące się nauczaniem i wychowaniem, jak i po prostu zainteresowane tą problematyką. Ludzie mają wiele pomysłów na to, jak ,wychować” dziecko, przy czym rady 
te zazwyczaj odnoszą się do cudzych dzieci, o czym można się przekonać np. podczas jazdy autobusem, gdy wzburzony dorosły zwraca uwagę obcej kobiecie, jak wychowała dziecko zajmujące miejsce siedzące, podczas gdy on stoi. Wiele analogicznych sytuacji można zaobserwować także w sklepie, gdy dziecko krzyczy, tupie nogami i domaga się kupna jakiegoś przedmiotu, a rodzic słyszy opinie przechodzących obok klientów w stylu: „Jak ja bym go wychował(a), to by się tak nie zachowywał”, „Jak można było do tego dopuścić?”. Takich przykładów można by wymienić wiele. Co istotne, należy mieć świadomość, że nie ma gotowych recept czy przepisów gwarantujących skuteczność wychowania, gdyż każdy człowiek jest niepowtarzalną jednostką, wymagającą indywidualnego podejścia. Nie oznacza to jednak rezygnacji i zaniechania profesjonalnych działań prowadzących do sukcesu wychowawczego.

Rozważania zamieszczone w niniejszym artykule mają na celu wskazanie warunków skuteczności wychowania realizowanego w środowisku szkolnym. Wydawać by się mogło, iż pedagodzy czynni zawodowo (adresaci i uczestnicy wielu szkoleń, kursów czy studiów podyplomowych) nie powinni mieć problemu ze skutecznym oddziaływaniem wychowawczym na swoich podopiecznych. Niestety, niejednokrotnie jest odwrotnie. Nauczyciele często nie radzą sobie $\mathrm{w}$ sposób zadowalający $\mathrm{z}$ wieloma problemami wychowawczymi, a w ramach prowadzonych godzin wychowawczych, zamiast realizować program wychowawczy, prowadzą lekcje $\mathrm{z}$ nauczanego przez siebie przedmiotu, thumacząc, iż uzupełniają w ten sposób zaległości w tym zakresie, albo zajmują się bieżącymi sprawami (m.in. usprawiedliwiają nieobecności, analizują oceny). Niewielu jest takich, którzy z pełną świadomością realizują program wychowawczy. A przecież szkoła to ,instytucja oświatowo-wychowawcza, zajmująca się zarówno kształceniem, jak i wychowaniem dzieci, młodzieży i dorosłych, stosownie do przyjętych w danym społeczeństwie celów i zadań oraz koncepcji oświatowo-wychowawczych i programów" (Okoń 2001, s. 383). Należy zaznaczyć, że funkcja kształcąca jest na pierwszym planie - to zwykle „wizytówka” szkoły, gdyż coraz częściej liczy się tylko to, które miejsce zajmuje w rankingu szkół z najwyższą średnią ze sprawdzianu dla uczniów kończących dany etap edukacyjny czy liczbą finalistów i laureatów olimpiad szkolnych. $Z$ tego powodu w walce o najwyższe podium nauczyciele przykładają wagę jedynie do tego, jaką wiedzę z danego przedmiotu posiada uczeń, a nie jak sobie radzi w kontaktach społecznych, jakie wartości są dla niego ważne. W efekcie uzyskanie pozycji najlepszej szkoły w mieście czy województwie odbywa się kosztem nie w pełni zrealizowanej funkcji wychowawczej. Czy to właśnie kryje się pod pojęciem „dobra szkoła”? Jakie są oczekiwania uczniów i rodziców odnośnie do szkoły? Czy wypełnianie przez szkołę funkcji wychowawczej w stopniu okrojonym do koniecznego zakresu rzeczywiście jest wystarczające? (Wosik-Kawala 2013, s. 9) Nie neguję tego, iż szkoła jest miejscem systematycznego zdoby- 
wania, poszerzania i zgłębiania wiedzy, lecz apeluję o podniesienie znaczenia funkcji wychowawczej, która powinna być realizowana w procesie edukacji przez wszystkich nauczycieli.

\section{USTALENIA TERMINOLOGICZNE}

W rozważaniach na temat wychowania w szkole podkreśla się współcześnie dwa aspekty - pierwszy dotyczy traktowania wychowania jako jednego $\mathrm{z}$ ważnych procesów społecznych, który nie jest autonomiczny, lecz związany z całokształtem życia, drugi zaś zakłada konieczność widzenia wychowania jako planowej i zamierzonej działalności społecznej (osób, grup lub instytucji) (Zubrzycka-Maciąg, Wosik-Kawala 2015, s. 15). Ze względu na podjętą problematykę przyjmuję rozumienie wychowania jako działalności celowej i planowej. W tej perspektywie można spotkać wiele różnych ujęć, ukazujących wychowanie w szerszym i węższym znaczeniu, a także jako oddziaływanie pośrednie i bezpośrednie czy dyrektywne i niedyrektywne. Na ogół wychowanie utożsamia się ze świadomym wywieraniem wpływu na wychowanka w celu przyswojenia lub utrwalenia pożądanych społecznie i moralnie cech jego osobowości (Łobocki 2006, s. 34). W sytuacji szkolnej ważne jest, aby zachowanie ucznia było zgodne z normami zapisanymi w statucie szkoły i regulaminie szkolnym oraz by młody człowiek świadomie dbał o przestrzeganie zasad współżycia społecznego i norm moralnych w myśl przyjętych zasad etyki.

Wincenty Okoń definiuje wychowanie jako:

(...) świadomie organizowaną działalność społeczną, opartą na stosunku wychowawczym między wychowankiem a wychowawcą, której celem jest wywołanie zamierzonych zmian w osobowości wychowanka. Zmiany te obejmują zarówno stronę poznawczo-instrumentalną, związaną z poznaniem rzeczywistości i umiejętnością oddziaływania na nią, jak i stronę emocjonalno-motywacyjną, która polega na kształtowaniu stosunku człowieka do świata i ludzi, jego przekonań i postaw, układu wartości i celu życia. (Okoń 2001, s. 445)

Badania prowadzone nad wychowaniem oraz teoretyczne rozważania w tym obszarze jak dotąd nie doprowadziły do opracowania jednej obowiązującej definicji wychowania, można natomiast wyodrębnić pewne jego cechy, które odnoszą się do wychowania rozumianego jako proces, a nie akt dokonany. Wychowanie rozpatrywane jako proces charakteryzuje: złożoność, intencjonalność, interakcyjność, relatywność i długotrwałość (Łobocki 1999, 2006).

Złożoność procesu wychowania wynika choćby z wielowymiarowości niektórych teorii psychologicznych tłumaczących mechanizm regulacji zachowań ludzkich (por. Kozielecki 2000). Współcześnie większość z nich łączy przekonanie, iż zachowanie człowieka zależy zarówno od uwarunkowań zewnętrznych 
(w tym oddziaływań wychowawczych), jak i uwarunkowań wewnętrznych, czyli od osobistych przeżyć i doświadczeń człowieka (jego potrzeb, aspiracji, motywów, dążeń) oraz funkcjonowania jego organizmu łącznie z centralnym systemem nerwowym. Również wszystko to, co oddziałuje na jednostkę z zewnątrz, wpływa przez uwarunkowania wewnętrzne na jej postępowanie. W wychowaniu chodzi nie tylko o zapamiętanie i zrozumienie pożądanych wychowawczo norm postępowania, ale także o ich pełną akceptację i uwewnętrznienie, a więc uczynienie z nich przewodniej idei w codziennym postępowaniu. $\mathrm{W}$ ten sposób nabywane przez wychowanka normy są przetwarzane w zasady własnego postępowania (Łobocki 2006, s. 53). Złożoność procesu wychowania powoduje, iż ma ono charakter relatywny, gdyż wiąże się z trudnościami, których nastręcza przewidywanie skutków oddziaływań wychowawczych. Na ogół takie przewidywanie ma charakter stwierdzeń hipotetycznych. Nie można z pełną odpowiedzialnością stwierdzić, iż stosowane przez nauczyciela metody wychowawcze (np. perswazja, karanie, nagradzanie) przyniosą taki sam efekt w przypadku dwóch uczniów. Hipotetyczny charakter wychowania pozwala stwierdzić, iż najprawdopodobniej metoda ta przyniesie pożądany skutek, jednakże złożoność wychowania (czyli zależność uwarunkowań zewnętrznych od wewnętrznych) uwrażliwia wychowawcę, że może być różnie. Należy bowiem pamiętać, że niekiedy większy wpływ ma to, co się dzieje wokół owego procesu, w tym zwłaszcza całokształt wpływów socjalizacyjno-inkulturacyjnych (Łobocki 2006, s. 56-57).

Kolejną istotną cechą wychowania jest intencjonalność. Oznacza ona, iż wychowawca jest świadomy celów, które pragnie realizować w trakcie planowo organizowanej działalności wychowawczej. Wychowanie obejmuje zatem wyłącznie wpływy intencjonalne (świadomie ukierunkowane), których celem jest oddziaływanie szczególnie na rozwój społeczny i moralny wychowanków lub wspomaganie ich w tym rozwoju (Łobocki 2006, s. 54-55). Wychowanie jest tym efektywniejsze, im bardziej zostanie ukierunkowane na aktywizowanie i usamodzielnianie wychowanków. Ma to miejsce w sytuacji interakcji, czyli opartego na zasadzie wzajemności współdziałania ze sobą wychowawcy i wychowanka. Skuteczność wychowania opartego na interakcji zależy z jednej strony od wyzwalania aktywności wychowanka, a z drugiej od tego, co wychowawca może zaoferować wychowankowi. Dlatego niezwykle ważne jest, aby nauczyciel dążył nie tylko do rozwoju i samodoskonalenia ucznia, ale też podejmował te wyzwania względem siebie. Można zauważyć, iż w procesie wychowawczym dokonują się zmiany w osobowości zarówno wychowanków, jak i wychowawców. W tym znaczeniu wychowanie to proces długotrwały, będący wyzwaniem dla wychowawcy i zobowiązaniem do ustawicznego doskonalenia własnej osobowości. Długotrwałość wychowania wymaga także systematyczności. Dłuższe przerwy w procesie wychowawczym mogą powodować zmarnowanie tego, co udało się osiągnąć, a nawet mogą wiązać się z niebezpieczeństwem wyraźnego cofania się w rozwoju społeczno-moralnym wychowanków (Łobocki 2006, s. 58). 


\section{PODSTAWOWE UWARUNKOWANIA SKUTECZNOŚCI PROCESU WYCHOWANIA W ŚRODOWISKU SZKOLNYM}

Istotnym warunkiem skutecznego wychowania jest przyjęcie przez nauczyciela określonej koncepcji człowieka (psychologicznej, filozoficznej, ideologicznej itp.), stanowiącej podstawę do określenia ideału wychowania, a w konsekwencji również sprecyzowania celów wychowania oraz zasad, form i metod ich realizacji. W zależności od przyjętego sposobu definiowania wychowania różne są role i zadania nauczycieli i uczniów. Należy przy tym pamiętać, że zdefiniowany ideał wychowania wyznacza efektywność sposobów realizacji jedynie tych celów wychowania, które są akceptowane w ramach danej ideologii. Oznacza to, że wywodzi się on z określonego systemu wartości, a następnie wskazuje drogi i warunki skutecznej realizacji celów wynikających z obranego systemu aksjologicznego. Można zatem uznać, że nie ma jednego celu wychowania, lecz jest ich wiele, w zależności od przyjętej ideologii wychowania. Niemniej, zabiegając o efektywność działań wychowawczych, można określić ich podstawowe uwarunkowania.

W procesie wspomagania ucznia w rozwoju kluczową funkcję pełni nauczyciel. Koniecznym warunkiem jego skutecznego działania, prowadzącego do realizacji priorytetowego celu wychowania (czyli inspirowania i wspomagania w rozwoju uczniów) jest posiadanie przez niego określonych cech osobowości oraz umiejętności potrzebnych w kontakcie z wychowankiem. Zbigniew Gaś na podstawie bogatej literatury odnoszącej się do tej problematyki wyłonił następujące cechy osobiste warunkujące efektywność wychowawczą w pracy z uczniami: świadomość siebie i swojego systemu wartości; przeżywanie i okazywanie uczuć; pełnienie funkcji modelowych dla uczniów; zainteresowanie ludźmi i sprawami społecznymi; jasne zasady etyczne; poczucie odpowiedzialności. Natomiast wśród warunków mających duży wpływ na proces wspomagania uczniów w ich rozwoju wymienił: empatię, ciepło i opiekuńczość; otwartość; pozytywny stosunek i szacunek dla wspomaganego; konkretność i specyficzność (Gaś 2001, s. 17).

Fundamentem, na którym nauczyciel buduje swoje relacje z uczniami, jest posiadany przez niego system wartości. Odgrywa on bardzo ważną rolę w strukturze osobowości człowieka, gdyż wyzwala emocje wobec siebie, innych ludzi oraz zjawisk i zdarzeń. Ponadto ma wpływ na kierunek i sposób zachowania w różnych sytuacjach życiowych, a także nadaje indywidualne piętno zachowaniom i działaniom człowieka (Wosik-Kawala, Lewandowska-Kidoń 2003, s. 55). Wartości są ważnym elementem budującym sytuację wychowawczą oraz dokonujący się na jej podłożu proces wychowania. Dlatego nauczyciel musi mieć świadomość swojego systemu wartości i umieć odpowiedzieć (głównie sobie) na pytania: Kim jestem? Co jest dla mnie ważne? Jaki jest mój system wartości? Nie chodzi tu jednak o wartości deklarowane, lecz o realizowane w życiu 
poprzez codziennie podejmowane decyzje i wybory, mimo rozterek, a czasami konfliktów. Tylko wtedy, gdy postępowanie nauczyciela jest zgodne z głoszonymi przez niego wartościami, ma on szansę na oddziaływanie wychowawcze na swoich podopiecznych. Zauważone przez uczniów rozbieżności między czynami a deklaracjami nauczyciela przyczyniają się do utraty możliwości bycia autorytetem oraz oddziaływania na uczniów, a więc warunkują odniesienie sukcesu wychowawczego.

Do ważnych cech nauczyciela wpływających na sukces wychowawczy należy wspomniana samoświadomość. Stanowi ona dynamiczną poznawczą reprezentację własnych stanów psychicznych (m.in. myśli, uczuć, cech). Nauczyciel świadomy samego siebie potrafi rozpoznać i ocenić pojawiające się w nim uczucia i emocje w związku z określonymi sytuacjami wychowawczymi, jest w stanie wskazać źródło własnych stanów psychicznych i nie przenosi ich na relacje $\mathrm{z}$ uczniem. Orientacja $\mathrm{w}$ sobie stanowi zatem pewnego rodzaju zabezpieczenie przed przenoszeniem emocjonalnych problemów nauczyciela na uczniów. Nie należą do rzadkości sytuacje, w których uczniowie obserwują zachowanie nauczyciela, by ocenić, „w jakim jest humorze”. Takie zachowanie nauczyciela wskazuje na jego niską samoświadomość oraz brak kompetencji pedagogicznych (Janowska 1993, s. 38-39).

Do czynników warunkujących budowanie pozytywnych kontaktów interpersonalnych pomiędzy nauczycielem a uczniami należy podmiotowe traktowanie uczniów. Oznacza ono humanistyczne podejście do wychowanków, uznanie ich prawa do niezależności i odrębności (niepowtarzalności). Tak rozumiana podmiotowość łączy się z ponoszeniem odpowiedzialności za swoje postępowanie (Łobocki 2006, s. 147). Dużą rolę odgrywa tu poszanowanie godności osobistej ucznia, a tym samym umacnianie w nim poczucia własnej wartości (Łobocki 1998, s. 16; Wojciechowska-Charlak 1997, s. 65). Przejawem podmiotowego podejścia do dzieci i młodzieży jest także okazywanie im akceptacji, empatii i bycie wobec nich autentycznym. Akceptacja uczniów polega na uznawaniu ich takimi, jakimi są, bez jakichkolwiek uprzedzeń. Wiąże się z respektowaniem ich prawa do odrębności, z pozwoleniem na to, by mogli różnić się od dorosłych. U podstaw akceptacji leży przekonanie, że każde dziecko to niepowtarzalna istota ludzka, mająca swój świat przeżyć, myśli i uczuć. Tak rozumiana akceptacja koreluje z okazywaniem wychowankom zaufania, szacunku i serdeczności oraz uniemożliwia nadawanie im tzw. etykiet, kwalifikowanie ich do określonej kategorii (np. ucznia łobuza, ucznia zdolnego, ale leniwego, ucznia trudnego) (Łobocki 1999, s. 80). Jednocześnie akceptacja dziecka nie oznacza uznania jego niepożądanych czy niewłaściwych zachowań, ponieważ należy je bezwzględnie modyfikować. W takim przypadku brak akceptacji odnosi się wyłącznie do popełnianego czynu, a nie do ucznia jako osoby. Okazywanie akceptacji wiąże się z wyrażaniem wobec wychowanków szacunku i serdeczności, co najczęściej ma wyraz w ogól- 
nym zainteresowaniu sprawami uczniów oraz odczuwanej wobec nich sympatii (Łobocki 1998, s. 17). Nauczyciel powinien być osobą tolerancyjną, przyznającą innym prawo do wyznawania poglądów, opinii czy pozwalającą na postępowanie odmienne od własnego. Powinien reprezentować postawę wykluczającą dyskryminację ludzi, których sposób postępowania oraz przynależność do danej grupy społecznej mogą podlegać dezaprobacie większości społeczeństwa (por. Okoń 2001, s. 405).

Kolejnym warunkiem podmiotowego traktowania ucznia jest rozumienie empatyczne. Najczęściej określa się tym terminem próbę wyobrażenia sobie tego, co czuje drugi człowiek. To zdolność rozumienia odczuć dzieci i młodzieży przez pryzmat ich sposobu widzenia świata, ludzi i wartości. Postawa ta jest przeciwstawna rozumieniu oceniającemu (Łobocki 1998, s. 17; Łobocki 1999, s. 81). Umożliwia spoglądanie na świat z punktu widzenia innych osób, przełamuje uprzedzenia, stereotypy, toruje drogę tolerancji i akceptacji różnic między ludźmi. Ta zdolność jest zazwyczaj warunkiem koniecznym do zmiany siebie i swojego zachowania na takie, które uwzględnia potrzeby innych ludzi (Potempska, Sobieska-Szostakiewicz 2003, s. 13). Empatia to warunek zrozumienia ucznia. Empatyczny nauczyciel może stworzyć uczniom poczucie bezpieczeństwa i komfortu psychicznego, ponieważ jest w stanie adekwatnie ich zrozumieć (Janowska 1993, s. 36). Zdolność rozumienia wewnętrznego świata doznań i przeżyć wychowanków umożliwia lepsze ich poznanie i zrozumienie motywów ich zachowania, a także wychodzenie naprzeciw ich potrzebom. Warunkiem przejawiania przez nauczyciela postawy empatycznej jest autentyczne zaangażowanie się przez niego w problemy swoich podopiecznych, trudno bowiem być empatycznym wobec drugiego człowieka w sytuacji, gdy nie jest dla nas ważny. Nie ma szans na odniesienie sukcesu wychowawczego nauczyciel, który w swojej pracy udaje czy gra swoją rolę bez jej uwewnętrznienia, który nie lubi swojej pracy, a wybór tej profesji traktuje jako zło konieczne. Jednym z wyznaczników skuteczności oddziaływań wychowawczych jest zatem identyfikacja z rolą zawodową.

Kolejną ważną cechą nauczyciela, warunkującą jakość jego relacji z uczniami, jest autentyzm. To zachowanie naturalne, nacechowane szczerością i spontanicznością. Oznacza zgodność uczuć i myśli z zachowaniem. Nauczyciel powinien być osobą mającą poczucie własnej godności i wartości jako istoty ludzkiej. Nie musi wstydzić się swoich błędów i niedomagań. Nie nakłada maski w kontaktach z uczniami, nie stara się być kimś innym, zrywa z fasadowością, graniem roli, zakłamaniem. Autentyczność nie oznacza jednak wyrażania wszystkich myśli i uczuć w różnych sytuacjach, zwłaszcza gdy można urazić innego człowieka (Łobocki 1998, s. 18; Łobocki 1999, s. 80-81). Co istotne, wiąże się ona z otwartością. Otwartość w kontaktach nauczyciel - uczeń sprzyja budowaniu atmosfery zaufania i życzliwości, umożliwia wzajemne poznanie, motywuje do rozwoju. Polega na okazywaniu tego, jak postrzegamy daną sytuację, jakie emo- 
cje i uczucia ona w nas wywołuje. To komunikowanie własnych uczuć i emocji powstałych na skutek i pod wpływem konkretnych zachowań i reakcji jednostki. Należy w tym miejscu podkreślić, iż każde uczucie jest wartością, natomiast niezwykle ważna jest umiejętność jego wyrażania (Janowska 1993, s. 35). Ważne jest to, by nauczyciel uczył, jak okazywać uczucia, jak dzielić się swoimi przeżyciami. Dla wielu uczniów uporanie się z niekontrolowanymi emocjami może być najtrudniejszym przedsięwzięciem pracy nad sobą. Dlatego cenne jest wsparcie ze strony nauczyciela w tym zakresie (Radochoński 2009, s. 27).

Szkoła jest miejscem, w którym są zdobywane informacje pozwalające na ocenę samego siebie, swoich umiejętności i predyspozycji. W odczuciu wielu ludzi obecny system wychowawczy wydaje się kształtować osoby raczej niepewne i nieświadome siebie. Zamiast wzmacniać i rozwijać samoocenę uczniów raczej pozbawia się ich pewności siebie, krytykuje i karze (Wosik-Kawala 2007, s. 11). $\mathrm{Z}$ tego powodu niezmiernie ważne jest, aby nauczyciel jako osoba podejmująca się zadania wychowania dzieci i młodzieży posiadał pozytywną, adekwatną samooc enę. „Samoocena to postawa wobec samego siebie, swoich cech, możliwości, zdolności i wad, stanowiąca emocjonalny komponent obrazu własnej osoby, czyli zespół różnorodnych sądów i opinii, które jednostka odnosi do swojej osoby, a dotyczą one jej fizycznych, psychicznych i społecznych właściwości” (Kirenko 2002, s. 128). Od tego, jak nauczyciel spostrzega i ocenia siebie, zależy efektywność jego działań, szczególnie w kontekście stosunku do innych osób. Nauczyciel o pozytywnej postawie do siebie będzie akceptował uczniów i utrzymywał z nimi korzystne stosunki interpersonalne; w przypadku nauczyciela o negatywnym stosunku do siebie kontakty z innymi osobami będą zaburzone (por. Wosik-Kawala 2008, s. 75). Poziom samooceny posiadanej przez nauczyciela w wysokim stopniu oddziałuje na umiejętność budowania przez niego klimatu wzajemnej akceptacji, zaufania i podmiotowego traktowania ucznia (Wosik-Kawala 2008, s. 75). Wzajemny kontakt między nauczycielem a uczniem zależy w dużej mierze od stopnia zaufania zbudowanego pomiędzy nimi. Wiarygodny nauczyciel ma szansę stać się dla swoich uczniów autorytetem i dzięki temu może mieć duże możliwości oddziaływania na nich. Na wiarygodność wychowawcy wpływają cztery czynniki: jawność intencji (odkrycie przez nauczyciela prawdziwych intencji wobec uczniów); przejawy ciepła i życzliwości (umiejętność okazywania uczniom sympatii); solidność jako źródło informacji (sprzyja jej logiczność myślenia, zdolność do trafnego przewidywania różnych wydarzeń i rozwoju sytuacji oraz rzetelność w przekazywaniu informacji); dynamika nadawcy, czyli zaangażowanie w to, co przekazuje (przekonanie o słuszności i znaczeniu tego, o czym się mówi zwiększa siłę przekazu, a przez to również wiarygodność) (por. Putkiewicz 1990, s. 115-116).

Na skuteczność wychowania w szkole znaczny wpływ ma umiejętność rozpoznawania przez nauczyciela potrzeb dzieci i młodzieży. Na podstawie literatu- 
ry przedmiotu dotyczącej definicji potrzeb (m.in. Obuchowski 1995; Reykowski 1970; Szewczuk 1998) można przyjąć, że potrzeba to niepożądany stan człowieka, odnoszący się do odczuwania przez niego braku dóbr, których posiadanie jest warunkiem życia lub zadowolenia z niego. Jednocześnie ukierunkowuje ona zachowanie i spostrzeganie człowieka oraz motywuje do aktywności skierowanej na jej zaspokojenie. Na podstawie tego stwierdzenia można wnioskować, iż wiele problemów i trudności, z którymi zmagają się uczniowie, jest efektem braku zaspokojenia przez nich potrzeb. Wiedza nauczyciela w tym zakresie może przyczynić się do zrozumienia przyczyn tego rodzaju zachowań i podjęcia kroków zaradczych czy kompensujących występujące braki. W rzeczywistości szkolnej niejednokrotnie bywa tak, że tzw. złe zachowanie ucznia wynika z niezaspokojonej potrzeby bezpieczeństwa, a brak skupienia się na treści przedmiotu przekazywanej przez nauczyciela - z braku snu lub z głodu. W tym miejscu warto zwrócić uwagę na najbardziej znaną w literaturze koncepcję potrzeb, której autorem jest Abraham Maslow (2006). Jego zdaniem w funkcjonowaniu potrzeb istnieje hierarchiczny porządek, na którego podstawie dokonał charakterystyki potrzeb ludzkich. Należy zaznaczyć, że zachowanie człowieka uwarunkowane jest wyłącznie przez potrzeby niezaspokojone.

Według Maslowa jeśli zostaną zaspokojone potrzeby stojące na początku hierarchii (potrzeby największej mocy, najsilniej determinujące zachowanie człowieka), wówczas uruchamiają się następne i te z kolei mogą być zaspokajane. Nie wyodrębnia on poszczególnych potrzeb, lecz grupuje je w pięć kategorii. Pierwsza grupa to potrzeby fizjologiczne (m.in. oddychania, odpowiedniej temperatury otoczenia, odżywiania, snu). Gdy w organizmie dominują potrzeby fizjologiczne, to inne zazwyczaj nie mają większego znaczenia. Ich zaspokojenie uwalnia organizm od dominacji fizjologicznych potrzeb i pozwala na pojawienie się innych, bardziej społecznych (Maslow 2006, s. 76). Fakt ten ma duże znaczenie dla wychowania, trudno bowiem motywować dziecko do nauki, gdy jest ono głodne, a swoje myśli koncentruje na sposobach zdobycia pożywienia. Niezaspokojenie tych potrzeb może zatem utrudniać prawidłowy rozwój pozostałych. Drugą grupę stanowią potrzeby bezpieczeństwa (m.in. stabilizacji, zależności, opieki, uwolnienia od strachu, lęku i chaosu, struktury porządku, prawa, ograniczeń, oparcia w opiekunie itp.). Człowiek stara się, by środowisko, w którym przebywa, było bezpieczne, uporządkowane, dające się przewidzieć, sprawiedliwe, w którym nie zdarzają się rzeczy nieoczekiwane, niedające się kontrolować, chaotyczne lub niebezpieczne i w którym istnieją opiekunowie chroniący (zwłaszcza dzieci) przed doznaniem krzywdy. Dom, w którym dziecko ma wyznaczone pory na sen, spożywanie posiłków czy odrabianie lekcji, mimo że może kojarzyć się z monotonią i życiem według utartego schematu, daje poczucie bezpieczeństwa, zwłaszcza gdy współgra $\mathrm{z}$ atmosferą akceptacji i współdziałania. Kolejną grupę stanowią potrzeby miłości i przynależności (m.in. dążenie do życia stadnego, gromadzenia 
się, przynależności, głód kontaktu, zażyłości). Dziecko, którego potrzeby z tej grupy nie zostały zaspokojone, łatwo może stać się członkiem grup nieformalnych o charakterze przestępczym lub członkiem sekty, może mieć symptomy choroby sierocej, przejawiać zachowania charakterystyczne dla nieprzystosowania społecznego czy też nie przestrzegać ogólnie przyjętych w społeczeństwie norm i wartości. Następną grupę stanowią potrzeby szacunku i uznania, a wśród nich dwie grupy: pierwsza to pragnienie osiągnięć, sprostania różnym zadaniom, mistrzostwa, kompetencji, zaufania do siebie wobec zadań życiowych oraz niezależności i swobody, druga zaś to pragnienie reputacji, prestiżu, sławy, zaszczytów, dominacji, uznania, wyróżnienia, ważności, godności czy docenienia. Deprywacja tych potrzeb wywołuje poczucie niższości, bezradności, braku sensu istnienia, zniechęcenia, braku motywacji do działania, tendencje kompensacyjne, a nawet neurotyzm. Gdy człowiek nie odczuwa braku w zakresie omówionych potrzeb, wówczas pojawiają się potrzeby samourzeczywistnienia, samoaktualizacji, które wyrażają się w dążeniu człowieka do rozwijania swoich potencjalnych możliwości. Ich zrealizowanie wiąże się z poczuciem spokoju, równowagi, zadowolenia. Dzięki tym potrzebom dziecko od najmłodszych lat dąży do przekraczania granic aktualnego stanu rozwojowego (Kirenko, Sarzyńska 2010, s. 47).

Oprócz wymienionych pięciu grup potrzeb Maslow wyróżnia również potrzeby poznawcze i estetyczne, lecz nie tworzy z nich dodatkowych grup. Potrzeba poznawcza jest uważana za podstawową, na co wskazuje gotowość do pokonywania przeszkód w celu jej zaspokojenia, występowanie patologii, gdy nie jest zaspokojona, oraz powszechność jej występowania. Należy w tym miejscu przypomnieć, iż reakcją na to, co dobrze znamy, jest znudzenie. Wśród symptomów pustki intelektualnej można wyróżnić: brak chęci do życia, niechęć do siebie, obniżenie sprawności funkcji cielesnych, obniżenie sprawności intelektualnej, upodobań itp. Dlatego warto, aby nauczyciel zadbał o to, by przekazywać dzieciom wiedzę w sposób wywołujący ich zaciekawienie, motywujący do działania. Uczeń dobrze zmotywowany z wytrwałością poświęca energię do osiągnięcia zamierzonego celu, podejmuje zadania stanowiące wyzwanie, w efekcie czego nauka szkolna pobudza jego zainteresowanie otaczającym światem, rodzi satysfakcję z wykonywanych działań i umacnia poczucie własnej wartości (Wosik-Kawala, Zubrzycka-Maciąg 2009, s. 69). Potrzeby estetyczne wiążą się z dążeniem do dokończenia danej czynności oraz potrzebą porządku. Chociaż u różnych osób przejawiają się inaczej i z różnym nasileniem, dobrze jest w wychowaniu dzieci zatroszczyć się o ich kształtowanie.

Biorąc pod uwagę przedstawioną koncepcję potrzeb Maslowa, należy dodać, że nauczyciel powinien zdawać sobie sprawę z konsekwencji, które wynikają z braku zaspokojenia przez uczniów odczuwanych przez nich potrzeb. Uczeń z niezaspokojonymi potrzebami fizjologicznymi (podstawowymi) będzie dążył w pierwszej kolejności do ich zaspokojenia, a dopiero później swoją aktywność 
skieruje na pozostałe, gdyż im wyższa potrzeba w ustalonej przez Maslowa hierarchii, tym mniejsze znaczenie ma dla biologicznego przetrwania, a jej zaspokojenie może być opóźnione, a nawet może ona zaniknąć. Trzeba przy tym zauważyć, że w sytuacji, gdy człowiek jest zdominowany przez jakąś potrzebę, to zmienia ona nie tylko jego aktualny światopogląd, ale także uznawane przez niego wartości oraz wizję przyszłości.

Należy mieć na uwadze, że głównym środowiskiem życia i oddziaływania wychowawczego na dziecko jest rodzina, dlatego bardzo duże znaczenie dla skuteczności przedsięwzięć wychowawczych nauczyciela ma współpraca z rodzicami. Głównym celem współdziałania nauczycieli i rodziców jest dążenie do usprawnienia pracy wychowawczej z uczniami (Łobocki 1985, s. 17). Istotne jest przekonanie obu stron co do tego, że wielostronny rozwój dziecka zależy od realizowanych wspólnie przez szkołę i dom działań. Współpraca to „działanie nauczycieli i rodziców zmierzające do urzeczywistnienia określonych celów, w tym zwłaszcza podejmowania wspólnych decyzji i konkretnych działań" (Łobocki 2007, s. 177). Nauczyciele bez nawiązywania bliskich kontaktów z rodzicami uczniów nie mają możliwości głębszego ich poznania i zrozumienia, a w konsekwencji wspólnego poszukiwania wyjścia z wielu trudnych sytuacji wychowawczych (Łobocki 2007, s. 181). Poznanie wychowanków to jeden z głównych warunków skuteczności wychowania. Dzięki znajomości indywidualnych możliwości i predyspozycji dzieci i młodzieży nauczyciel może tak dobierać metody wychowania i nauczania, aby uczeń miał możliwość odniesienia sukcesu, by czuł się kimś, na kim nauczycielowi zależy, dla którego jest ważny i wartościowy. Spojrzenie na ucznia w sposób nieoceniający można odnaleźć także w teorii inteligencji wielorakich, opartej na założeniu, że ludzie mają różne zdolności poznawcze i odmienne style poznawania (Gardner 2009, s. 6). Zastosowanie w praktyce teorii Howarda Gardnera wymaga znajomości każdego ucznia i określenia dominującej u niego jednej z ośmiu inteligencji.

W celu lepszego poznania uczniów nauczyciel może stosować obserwację, wywiad, rozmowę z uczniem, rodzicem, techniki projekcyjne. W pracy diagnostycznej pedagoga najczęściej wykorzystuje się klasyfikację technik projekcyjnych Porota, który wyróżnia techniki wizualne (obrazkowe), werbalne, zabawowe i graficzne (zob. Wosik-Kawala, Grabowiec 2013). Oprócz poznania cech indywidualnych ucznia ważna jest diagnoza jego zachowania $\mathrm{w}$ grupie. $\mathrm{W}$ tym celu nauczyciel może zastosować następujące techniki socjometryczne: klasyczną Moreno; plebiscyt życzliwości i niechęci; zgadnij kto?; szeregowania rangowego. Techniki te mogą stanowić dużą pomoc dla nauczyciela w identyfikowaniu uczniów izolowanych i odrzucanych w grupie, tak by mógł podjąć działania zmierzające do ich integracji z klasą. Umożliwiają poznanie, kto w grupie jest tzw. gwiazdą socjometryczną, czy są osoby izolowane bądź odrzucane, które osoby tworzą paczkę i czy istnieją łańcuchy socjometryczne. Ponadto pozwalają na pod- 
jęcie działania mającego na celu integrację klasy. W procesie wychowania ważne jest, aby nauczyciel potrafił też „zarazić” uczniów swoimi pasjami. Odsłaniając część swojej osobowości, może uczyć, jak okazywać uczucia, jak dzielić się przeżyciami, poza tym powinien rozwijać zainteresowania uczniów, by każdy z nich czuł się doceniony i potrzebny (Kacprzak 2006, s. 314).

\section{ZAKOŃCZENIE}

Proces wychowania jest uwarunkowany wieloma czynnikami. Wiąże się przede wszystkim ze zrozumieniem przez jednostkę określonych norm społecznomoralnych oraz nadaniem tym normom znaczenia osobistego (Okoń 2001, s. 445). Zaprezentowane w niniejszym opracowaniu uwarunkowania procesu wychowania z pewnością zbliżą nauczyciela do osiągnięcia pozytywnych rezultatów wychowawczych w pracy z dziećmi i młodzieżą. Zdaję sobie sprawę, iż lista zaprezentowanych elementów wpływających na efektywność procesu wychowania w środowisku szkolnym stanowi jedynie część omawianego zagadnienia, w moim odczuciu będącą pewnym fundamentem efektywnego wychowania. Mam nadzieję, że lektura treści zawartych w tym artykule zachęci pedagogów do podjęcia trudu praktycznego wdrożenia omawianych elementów do pracy z dziećmi i młodzieżą.

\section{BIBLIOGRAFIA}

Gardner H. (2009), Inteligencje wielorakie. Nowe horyzonty w teorii i praktyce, Warszawa: Laurum. Gaś Z. (2001), Doskonalacy się nauczyciel, Lublin: Wydawnictwo UMCS.

Janowska J. (1993), Samoaktualizacja w teorii i praktyce kształcenia nauczycieli, Lublin: Wydawnictwo UMCS.

Kacprzak L. (2006), Pedeutologiczne rozważania o nauczycielu, Piła: Państwowa Wyższa Szkoła Zawodowa im. Stanisława Staszica.

Kirenko J. (2002), Wsparcie społeczne osób z niepetnosprawnością, Ryki: WSUPiZ.

Kirenko J., Sarzyńska E. (2010), Bezrobocie, niepetnosprawność, potrzeby, Lublin: Wydawnictwo UMCS.

Kozielecki J. (2000), Koncepcje psychologiczne czlowieka, Warszawa: Wydawnictwo Akademickie „Żak”. Łobocki M. (1985), Współdziałanie nauczycieli i rodziców w procesie wychowania, Warszawa: Nasza Księgarnia.

Łobocki M. (1998), Czynniki warunkujące skuteczność pracy wychowawczej, [w:] M. Łobocki (red.), Praca wychowawcza z dziećmi i młodzieża, Lublin: Wydawnictwo UMCS.

Łobocki M. (1999), ABC wychowania, Lublin: Wydawnictwo UMCS.

Łobocki M. (2006), Teoria wychowania w zarysie, Kraków: Oficyna Wydawnicza Impuls.

Łobocki M. (2007), W trosce o wychowanie w szkole, Kraków: Oficyna Wydawnicza Impuls.

Maslow A. (2006), Motywacja i osobowość, Warszawa: Wydawnictwo Naukowe PWN.

Obuchowski K. (1995), Przez galaktykę potrzeb. Psychologia dążeń ludzkich, Bydgoszcz: Zysk i S-ka. 
Okoń W. (2001), Nowy słownik pedagogiczny, Warszawa: Wydawnictwo Akademickie „Żak”.

Potempska E., Sobieska-Szostakiewicz G. (2003), Rozwój empatii i kompetencji społecznych, Warszawa: Centrum Metodyczne Pomocy Psychologiczno-Pedagogicznej.

Putkiewicz E. (1990), Proces komunikowania się na lekcji, Warszawa: WSiP.

Radochoński M. (2009), Psychopatologia życia emocjonalnego dzieci i młodzieży. Wybrane zagadnienia, Rzeszów: Wydawnictwo Uniwersytetu Rzeszowskiego.

Reykowski J. (1970), Natura ludzka a potrzeby, „Etyka”, nr 6.

Szewczuk W. (1998), Encyklopedia psychologii, Warszawa: Fundacja Innowacja.

Wojciechowska-Charlak B. (1997), Podmiotowość w wychowaniu, [w:] T.E. Dąbrowska, B. Wojciechowska-Charlak, Między praktyką a teoria wychowania, Lublin: Wydawnictwo UMCS.

Wosik-Kawala D. (2007), Korygowanie samooceny uczniów gimnazjum, Lublin: Wydawnictwo UMCS.

Wosik-Kawala D. (2008), Rola samooceny w zapobieganiu patologiom życia społecznego - kontekst psychopedagogicznego przygotowania studentów, „Lubelski Rocznik Pedagogiczny”, t. 27.

Wosik-Kawala D. (2013), Rozwijanie kompetencji emocjonalnych uczniów szkół ponadgimnazjalnych, Lublin: Wydawnictwo UMCS.

Wosik-Kawala D., Grabowiec A. (2013), Techniki projekcyjne w pracy pedagoga, [w:] V. Korim, R. Uździcki (red.), Szkoła w perspektywie jej realnych przeobrażen. Zarządzanie-kompetencje - kreatywność, Toruń: Wydawnictwo Adam Marszałek.

Wosik-Kawala D., Lewandowska-Kidoń T. (2003), Wartości uznawane przez wychowanków placówek opiekuńczo-wychowawczych, [w:] B. Wojciechowska-Charlak (red.), Praca opiekuńczowychowawcza, Kielce: Wszechnica Świętokrzyska.

Wosik-Kawala D., Zubrzycka-Maciąg T. (2009), Motywowanie uczniów do nauki - wskazówki dla nauczyciela, „Studium Vilnense A.”, t. 6.

Zubrzycka-Maciąg T., Wosik-Kawala D. (2015), Wychowanie w szkole. Wskazówki dla nauczycieli, Lublin: Wydawnictwo UMCS.

\section{SUMMARY}

Nowadays, the school is expected to be an educational institution that protects the individual's individuality, helping her to manage her own development and strive for self-realization, preparing her for valuable participation in social life. Although education in school is done every day, through interaction with all teachers and peers, the teacher, especially the class teacher, is responsible for the effects of the educational process. This is an analytical-demonstrative article and it shows the theoretical context concerning the basic factors affecting the effectiveness of the education process carried out in the school environment. Education is understood here as the process of shaping a young person and is defined by its five main features. The author points out that people involved in education due to their professional role should base their approach on clearly defined guidelines, formulated in a transparent and legible manner, taking into account the basic principles of interpersonal relationships, and not only on intuition and own experience.

Keywords: school; education; teacher; student 